DOI:

\title{
Structural Performance of Strengthened Steel Girders with Web Openings under Shear Forces
}

\author{
Mohamed F. Ezzat ${ }^{*}$, Mohamed A. Elsabaawy ${ }^{2}$ and Boshra A. Eltaly ${ }^{2}$ \\ ${ }^{1}$ Civil Engineering Department, Higher Institute of Engineering and Technology in Kafr El-sheikh \\ ${ }^{2}$ Civil Engineering Department, Faculty of Engineering, Menoufia University. \\ * Corresponding author: m.f750718@gmail.com
}

\begin{abstract}
The use of Steel Beams with Web Openings such as industrial and multistoried buildings has evicted to be wide in recent times. The existing study goals to examine the structural performance of steel beams with web openings in the shear zones and detect the chance of using carbon fiber reinforced polymer epoxy laminates as a composite material for the strengthening process. The shapes, numbers of web openings where the openings area is constant for all beams, places and thickness of composite material for strengthening beams were the main parameters. The behavior of ten steel beams which contain beams with opening, beams without openings and beams strengthened with different forms were specified by a Finite Element Model. An experimental program performed in the current work for four beams; control beam where there is without openings and number of three beams with web openings. The finite element results display a good agreement with the analogical values detected in the experiments. The results displayed that the beams with circular openings are better than those with rectangular openings and opening height is an important parameter. The composite material is a right strengthening selection in the shear and tension zone. Increased composite material thickness is comparatively useless, where most of the time, the failure is due to de-bonding (adhesive material) not rupture in composite material laminates.
\end{abstract}

Keywords: Steel; beam; openings; shear; Strengthening.

\section{Introduction}

Modern multistoried structures always have a stiff requirement on the headroom to involve buildings facilities like Water lines, Electrical lines; Fire exists, etc. Web openings system is beneficial where this system of construction leads to reducing the floor depth by-passing building facilities through web openings which are useful to decrease the height of this building. Web openings system is useful for check and maintenance in the installation of pipes or ducts. Web openings in girders are presented to lessen the structure weight and offer a good architectural state. Circular and rectangular openings are widely used. Sometimes such pre-engineered buildings are with a large span but relatively subjected to fewer loading and the steel section is safe in strength condition, however, section does not gratify serviceability requisites so it gets needed to use beams with large depths to meet this required. Using open web beams is the ideal solution to conquer this difficulty. The common method of strengthening or repairing steel structures is to cut out and return plating, or to connect exterior steel plates. These plates are generally huge, weighty, not easy to fix, and apt to fatigue and erosion. The alternatives are needed. The usage of FRP (Fiber Reinforced Polymer) seems to be a great solution. FRP owns a great strength to weight ratios and good resistance to erosion and environmental degeneration. Morkhade and Gupta [1] investigated the performance of steel girders with web openings using an experimentally and a theoretical study. Kumbhar and Jamadar [2] introduced a perfection of opening dimensions for a castellated beam with sinusoidal openings. They used an experimental and a theoretical study. It was discovered that castellated beams with sinusoidal openings were well than the other formed openings in deference of taking loads. De'nan, Keong, and Hashim [3] investigated the effect of shapes and sizes of web opening on the bending behavior of I-beam. Mohan and Prabhakaran [4] presented a finite element analysis (FEA) by software ANSYS 14.5. They presented the deflection of steel beams with and without web openings. Parameters were opening shape. Liu and Chung [5] investigated the performance of steel beams with big web openings of different sizes and forms by the finite element method. They found that all steel beams with web openings of different forms and sizes progress 
similarly between each other in deformed shapes under a large range of moment and shear force. Fahmy and Hassanein [6] introduced an analysis of composite beams with web openings. $\mathrm{Li}$, et al. [7] introduced an experimental study to observe the mechanical performance and load capacity of continuous composite beams with web openings. ElShaer [8] presented a non-linearity FEA to study the deflection of steel section and internal stresses of the concrete slab for continuous composite beams with one rectangular opening in the web of the steel section. Dawood and Al-Saffar [9] presented the structural performance of composite beams in which a concrete slab was joined with a steel beam by headed stud shear connector or by epoxy layer as a shear connector. The main parameters were numbers and locations of web openings. Prakash et al. [10] presented strengthening about rectangular web openings of steel beam. They used FEA ANSYS to analyze the steel beams. Variables were opening location for the beam span from $0.1 \mathrm{~L}$ to $0.9 \mathrm{~L}$, ratio of opening height to the height of the beam which was $0.50,0.62,0.75$, aspect ratios from 1.0 to 2.0 and strengthening by steel plates which provided around the opening perpendicular to the web and parallel to width of the opening. Ghafoori and Motavalli [11] investigated the elastic performance of steel beams strengthened using normal, high and ultra-high modulus of Carbon Fiber Reinforced Polymer (CFRP) laminates by bonded and un-bonded techniques. Each kind of laminate was connected to the steel beams using bonded and un-bonded reinforcement systems. The study concluded that all three categories of NM, HM and UHM CFRP laminates; the Young's modulus raises gradually with the rise in applied strain in the laminates, strengthening of the steel beams using the un-bonded system took under half of the time that was required for strengthening with the bonded system and the inplane stiffness of the retrofitted beams rest on Young's modulus of the applied CFRP laminate where the higher capacity for higher Young's modulus. Altaee, Cunningham and Gillie [12] introduced an experimental study of CFRPstrengthened steel beams with web openings. Beams were a control beam without opening and three unstrengthened beams with an opening at changed places of the beam span and three beams strengthened by CFRP plates. Only control beam and three strengthened beams with openings were tested experimentally. The study achieved that all of the strengthened sections examined, a stiffer response was observed till the ultimate load encroach in the un-strengthened cases. Further, in all cases the strengthened beams displayed higher load capacity after strengthening with web openings encroach the control case with no openings. Narmashiri et al.[13] presented the effect of using mechanical fixing clamps to avert de-bonding. Clamps were created by bolting the CFRP to the steel. The results display that the load capacity raised by $24 \%$ linked to that of the non-clamped, adhesive-fixed plate. Rigi and Narmashiri [14] presented seven of steel beam samples. Beams were studied for modeling by ABAQUS V6.11. They included one beam sample without strengthening, two samples with vertical strengthen in the shear zone in the form of one side and both sides, and four diagonal strengthening samples on one side and both sides. Diagonal strengthening and in both sides shows the highest resistance and load capacity in evaluation with other strengthening methods. Linghoff et al. [15] introduced the behavior of the strengthened beams with changed forms of CFRP laminates. Laboratory tests and analytical solutions were used. The results displayed that it is probable to raise the moment capacity of a steel beam with CFRP bonded to its tension flange. Also, estimation the magnitude of the increase in capacity using simplified analytical solutions. In the current research, ten simple steel beams were studied using the FE analysis program, ANSYS V15 to study their structural behavior until failure in terms of ultimate load and its related deflection, the normal and shear stresses and the strain. A steel beam without openings was used and was named a control beam. Three beams with web openings. Six steel beams with web openings strengthened by CFRP laminates. To verify the FE analysis, four experimental steel beams were studied. In the current study, five variables were studied; openings shape, openings number, openings height and the strengthening by CFRP laminate. The strengthening includes shape, place and thickness of strengthening materiel (CFRP laminate). To the best of the authors' knowledge of this work, there is evaluating and investigating the effect of beam parameters that with equal web opening areas in shear zones and strengthening by CFRP laminates in different places with different thickness. Hence, it is a good plan to perform a complete investigation using FE analysis, experimental work technique to analyze the influence of structural performance of strengthened steel girders with web openings under shear forces. Thus, these results can be a reference for engineers who are interested to search for design steel beams with web openings and strengthened them.

\section{FE Model}

In the finite element models (FEM), a solid element (solid 185) was used to model steel beams and CFRP laminates, while (Solid 65) was used to model 


\section{Mohamed F. Ezzat, Mohamed A. Elsabaawy and Boshra A. Eltaly "Structural Performance of Strengthened Steel Girders with Web Openings Under Shear Forces"}

adhesive material. When describing the mesh size for beams, accurate and best results were wanted. The hexahedral was appropriate in terms of time and regular shapes; tetrahedral was suitable for irregular shapes. Therefore, a $4 \mathrm{~mm}$ dimension tetrahedral mesh was used in the openings zones of the beam, CFRP laminates and adhesives material, and a $10 \mathrm{~mm}$ dimension hexahedral mesh worked in the remainder of the beam. The aim for decreasing the dimension value of mesh from $10 \mathrm{~mm}$ to $4 \mathrm{~mm}$ at shear zones, CFRP laminates and adhesive material is a stress concentration in these zones and small thickness of CFRP laminates, adhesive material to preserve the aspect ratio. Geometric nonlinearity and material nonlinearity were chosen. The material nonlinearity was defined as a multilinear stress-strain curve kinematic hardening constants approach. The analysis took the large deformation effects. Figure (1) shows the FE simulation of the control beam.

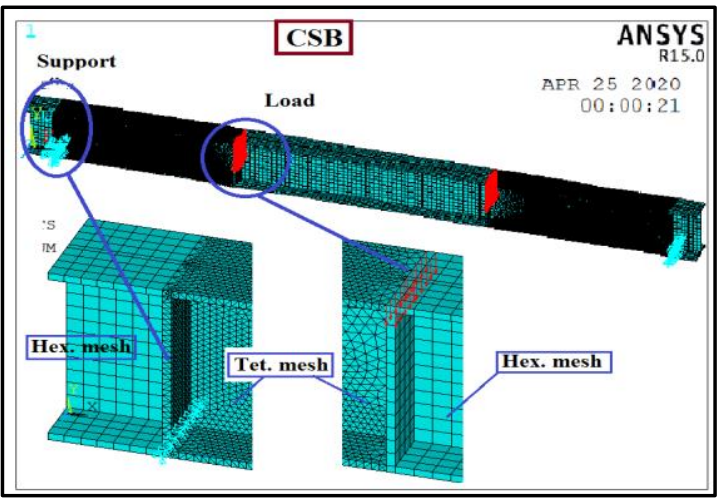

Figure 1: Numerical Model

\section{Specimen Details}

The behavior of ten steel beams with I cross-section as displayed in Table (1) was examined in these sections. The overall depth was $120 \mathrm{~mm}$, top and bottom flange width was $65 \mathrm{~mm}$, the thickness of flange was $4.7 \mathrm{~mm}$ and web thickness was $3.6 \mathrm{~mm}$. Transverse stiffeners on two sides of the beam web were made of flat plates; $30.7 \mathrm{~mm}$ wide and $5 \mathrm{~mm}$ thickness. The beam span was $1372 \mathrm{~mm}$ and the total length was $1500 \mathrm{~mm}$ and the distance between the two applied loads was $560 \mathrm{~mm}$ see Figure (2). One steel beam without opening named Control beam (CSB), three steel beams were with web openings in the shear zones (SBWOs1, SBWOs2, SBWOs3). From results of beams with openings (SBWOs1, SBWOs2, SBWOs3) as presented below, it can be found that the beam with rectangular openings was the weakest beam in capacity load so six strengthened beams (S1SBWOs3, S2SBWOs3, S3SBWOs3, S4SBWOs3, S5SBWOs3, S6SBWOs3) with CFRP laminates, different technics and CFRP thickness were studied till failure. CSB beam was called by this name acronym for words control steel beam. For SBWOs1 beam, SB refers to a steel beam, WO refers to web openings and number one indicates the first beam. For SBWOs2 beam, SB refers to a steel beam, WO refers to web openings and number two indicates the second beam. For SBWOs3 beam, SB refers to a steel beam, WO refers to web openings and number three indicates the third beam. S1SBWOs3 beam, S1 refers to the first strengthening beam and SBWOs3 indicates that the strengthening was done on the SBWOs3 beam. S2SBWOs3 beam, S2 refers to the second strengthening beam and SBWOs3 indicates that the strengthening was done on the SBWOs3 beam. S3SBWOs3 beam, S3 refers to the third strengthening beam and SBWOs3 indicates that the strengthening was done on the SBWOs3 beam. S4SBWOs3 beam, S4 refers to the fourth strengthening beam and SBWOs3 shows that the strengthening was done on the SBWOs3 beam. S5SBWOs3 beam, S5 refers to the fifth strengthening beam and SBWOs3 indicates that the strengthening was done on the SBWOs3 beam. S6SBWOs3 beam, S6 refers to the sixth strengthening beam and SBWOs3 indicates that the strengthening was done on the SBWOs3 beam.

Table 1- Beams description

\begin{tabular}{cc}
\hline $\begin{array}{c}\text { Beam } \\
\text { Name }\end{array}$ & Description \\
\hline CSB & Control Steel beam without opening \\
\hline SBWOs1 & $\begin{array}{c}\text { Steel beam with six circular openings, } \\
74 \text { mm diameter }\end{array}$ \\
\hline SBWOs2 & $\begin{array}{c}\text { Steel beam with four circular } \\
\text { openings, 90 mm diameter }\end{array}$ \\
\hline SBWOs3 & $\begin{array}{c}\text { Steel beam with four rectangular } \\
\text { openings, 71 mm width and 90 mm } \\
\text { height }\end{array}$ \\
\hline S1SBWOs3 & $\begin{array}{c}\text { Strengthened at web between the } \\
\text { openings, } 1.2 \text { mm thickness }\end{array}$ \\
\hline S2SBWOs3 & $\begin{array}{c}\text { Strengthened at the lower flange, 1100 } \\
\text { mm length and 1.2 mm thickness. }\end{array}$ \\
\hline S3SBWOs3 & $\begin{array}{c}\text { Strengthened at the lower flange and } \\
\text { the web, 1.2 mm thickness. }\end{array}$ \\
\hline S4SBWOs3 & $\begin{array}{c}\text { Strengthened at web between the } \\
\text { openings, } 1.4 \text { mm thickness. }\end{array}$ \\
\hline S5SBWOs3 & $\begin{array}{c}\text { Strengthened at the lower flange, 1100 } \\
\text { mm length and 1.4 mm thickness. }\end{array}$ \\
\hline S6SBWOs3 & $\begin{array}{c}\text { Strengthened at the lower flange and } \\
\text { the web, 1.4 mm thickness. }\end{array}$ \\
\hline
\end{tabular}



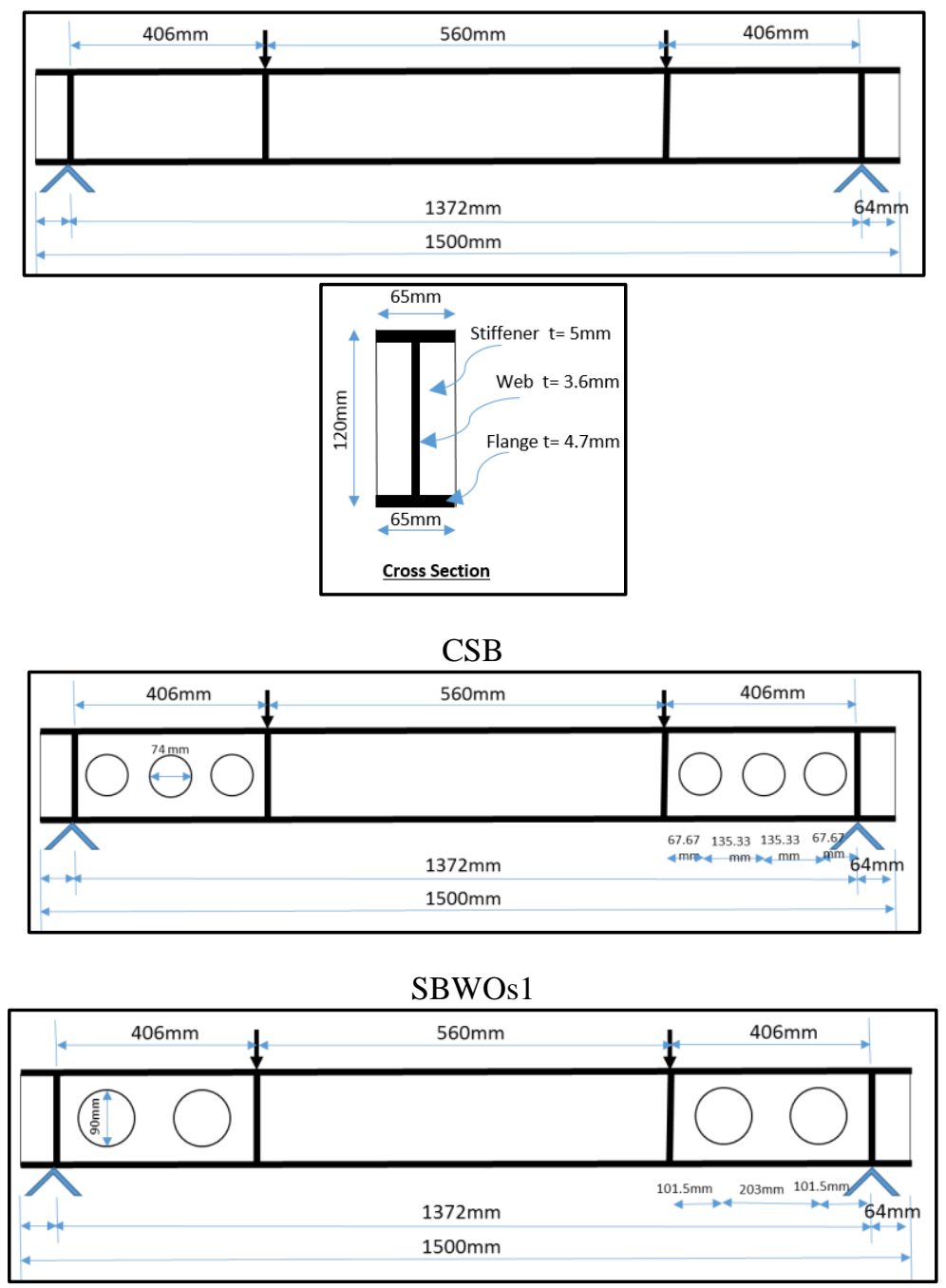

SBWOs2

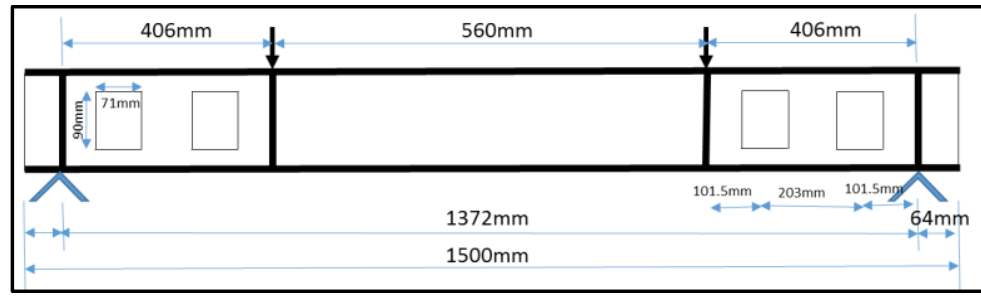

SBWOs3

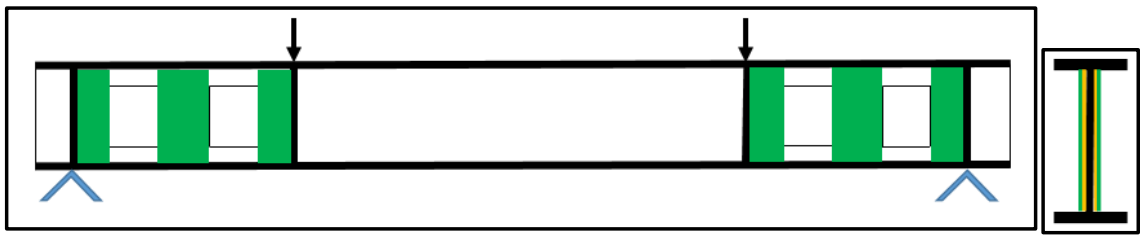

S1SBWOs3 and S4SBWOs3

Figure 2: Specimens Layout 

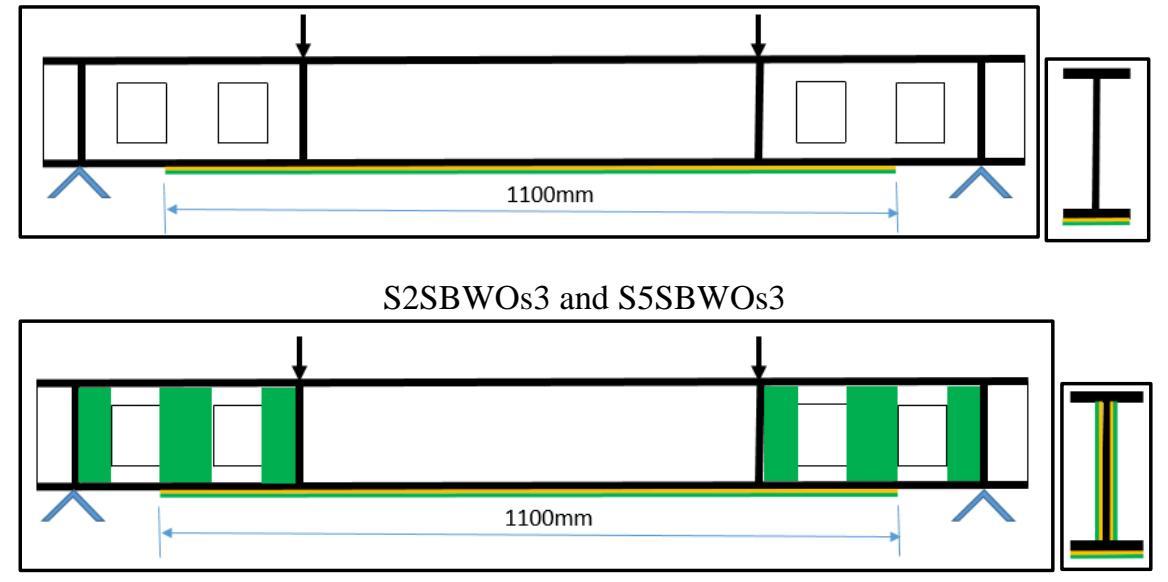

S3SBWOs3 and S6SBWOs3

Figure 2- continued: Specimens Layout

\section{Material properties}

Properties of steel beams were got by Single-axis tensile test conducted on three samples of $206 \mathrm{~mm}$ long, $35 \mathrm{~mm}$ wide cut from the web of the used steel beams which was gotten from the Egyptian market (see Table (2)). Sika CarbodurR S1012 and Sika CarbodurR S1014 (CFRP laminates) with $1.2 \mathrm{~mm}$ and $1.4 \mathrm{~mm}$ thickness, respectively were used in strengthening the beams. The properties of CFRP material were taken from the technical data sheets of the Sika Egypt Company (see Table (3)). SikadurR30 was used for connecting CFRP to the steel beam. It was resin and a hardener (see Table (4)).

Table 2- Properties of steel materials

\begin{tabular}{ccccc}
\hline $\begin{array}{c}\mathrm{E} \\
(\mathrm{GPa})\end{array}$ & $\begin{array}{c}\mathrm{Fy} \\
(\mathrm{MPa})\end{array}$ & $\begin{array}{c}\mathrm{Fu} \\
(\mathrm{MPa})\end{array}$ & $\begin{array}{c}\text { Yielding } \\
\text { strain \% }\end{array}$ & $\begin{array}{c}\text { Ultimate } \\
\text { strain \% }\end{array}$ \\
\hline 200000 & 340 & 480 & 0.17 & 20 \\
\hline
\end{tabular}

Table 3- Properties of CFRP laminates material

\begin{tabular}{ccccc}
\hline $\begin{array}{c}\text { CFRP } \\
\text { type } \\
(\text { Trade } \\
\text { Mark) }\end{array}$ & $\begin{array}{c}\mathrm{E} \\
(\mathrm{GPa})\end{array}$ & $\begin{array}{c}\mathrm{Fu} \\
(\mathrm{MPa})\end{array}$ & $\begin{array}{c}\text { Strain } \\
\text { at } \\
\text { break }\end{array}$ & $\begin{array}{c}\text { Thickness } \\
(\mathrm{mm})\end{array}$ \\
\hline $\begin{array}{c}\text { Sika } \\
\text { Carbodur } \\
\text { R }\end{array}$ & 165 & 2900 & 1.8 & 1.2 \\
\hline $\begin{array}{c}\text { Sik12 } \\
\text { Sika }\end{array}$ & & & & \\
$\begin{array}{c}\text { Carbodur } \\
\text { S }\end{array}$ & 165 & 2900 & 1.8 & 1.4 \\
\hline
\end{tabular}

Table 4- Properties of adhesive material

\begin{tabular}{cccc}
\hline $\begin{array}{c}\text { Adhesive type } \\
\text { (Trade Mark) }\end{array}$ & $\begin{array}{c}\mathrm{E} \\
(\mathrm{MPa})\end{array}$ & $\begin{array}{c}\text { Fu } \\
(\mathrm{MPa})\end{array}$ & $\begin{array}{c}\text { Thickness } \\
(\mathrm{mm})\end{array}$ \\
\hline Sikadur $^{\mathrm{R}}-30$ & 11200 & 30 & 1.0 \\
\hline
\end{tabular}

A 3-D FEM contained solving for all beams and experimental work was developed to confirm the FEA. Only four steel beams (CSB, SBWOs1, SBWOs2, SBWOs3) were tested experimentally. Manufacturing web openings in the beams without any negative effect on the beam was required. A steel laser cutting machine was the first proposal but, a problem appeared. It was not enough clearance of laser machine pen where the diameter of the pen almost equal $30 \mathrm{~mm}$ which needs $15 \mathrm{~mm}$ clearance after the opening. This was not available in the current study due to the presence of openings in the web (between two flanges) and the distance between the opening and the flange less than the laser machine pen; $15 \mathrm{~mm}$ each side. So a second proposal was considered. It was Oxy-gas cutting but there were weaknesses in this method where openings borders were not soft, effecting of gas temperature on steel materials at opening edges and openings sizes were not exact. This method was excluded. The third proposal was considered; it was a Fraisage machine and drill machine where making rectangular openings by Fraisage machine and circular openings by drill machine. This method was the appropriate method for the current case where that produced an accurate dimension of openings and good opening edge this all without any defects on steel material properties. Vertical stiffeners with a thickness $5 \mathrm{~mm}$ were welded at the load position on both sides of the beam web to evade stress concentration at these points which may cause local failure. Angles 60x60x6 mm were used as supports for every beam to simulate the hinged supports. A flexural testing machine with an ability of $100 \mathrm{kN}$ was used for specimens loading. The deflections of the tested beams were measured at 
three measuring points D1, D2 and D3; middle of the left-hand shear zone, mid-span and middle of the right-hand shear zone respectively, using dial gauges with $0.01 \mathrm{~mm}$ accuracy. Compression and tensile strains were observed by two mechanical strain gauges. Figure (3) shows the test set-up.
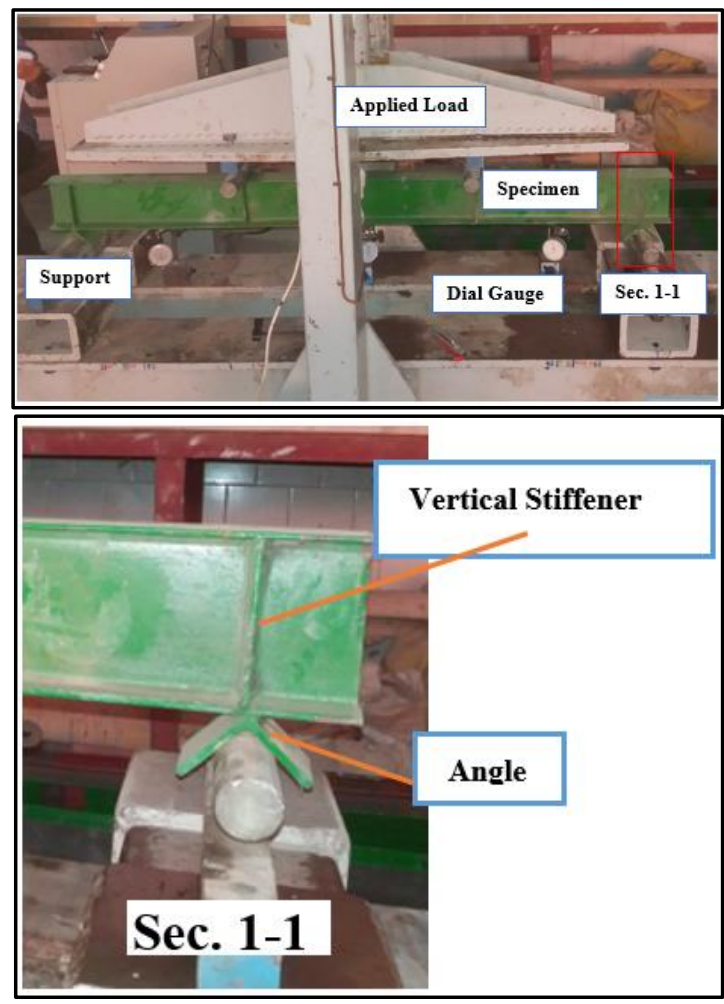

Figure 3- Load set up of CSB

\section{Results and Discussion}

\subsection{Verification of Finite Element Model}

The performance and behavior of the tested beams were shown in Table (5). Each test was done from starting till the failure. The load was the total of two concentrated load and the deflection was at the midspan for all tested specimens. The yielding load and its corresponding mid-span deflection, the failure load and its corresponding mid-span deflection, the energy absorption, the stiffness, the ductility ratio and the failure mode of all beams as results were recorded in Table (5). The energy absorption was approximately calculated as the area enclosed by the load-deflection curve at the mid-span. The ductility ratio was computed as the relation between the midspan deflections at the failure load and at the yielding load while the stiffness was considered as the load divided on corresponding deflection at the linear zone end. The results indicated that CSB was the highest in the values of ductility, stiffness and energy absorption. Good agreement between experimental work and FEA specifically at the openings as shown in Figure (4) and the load-deflection curves of the four beams see Figure (5). The ultimate load of CSB was $82 \mathrm{kN}$, with a $70 \mathrm{~mm}$ deflection value. The ultimate load of SBWOs1 was $70 \mathrm{kN}$, with a 11.50 $\mathrm{mm}$ deflection value. The ultimate load of SBWOs2 was $54 \mathrm{kN}$, with a deflection value $8 \mathrm{~mm}$. The ultimate load of SBWOs3 was $44 \mathrm{kN}$, with a $9 \mathrm{~mm}$ deflection value. The occurring distortion in the rectangle opening was larger than in the circle opening. Normal Stresses concentration happened at the four corner points of the rectangular opening in a diagonal shape. Two diagonal corners were tension stress and the other two diagonal corners were compression stress. This concentration decreases two diagonal angles values which subjected to compression stresses and increase the other two diagonal angles values which subjected to tension stresses and rupture of this corner see Figure (6).

Table 5- Experimental results

\begin{tabular}{|c|c|c|c|c|c|c|c|c|c|}
\hline \multirow{2}{*}{$\begin{array}{l}\text { Beam } \\
\text { No. }\end{array}$} & \multicolumn{2}{|c|}{ Yield } & \multicolumn{2}{|c|}{ Ultimate } & \multirow{2}{*}{$\begin{array}{l}\text { Energy } \\
\text { Absorb. } \\
\text { kN.mm }\end{array}$} & \multirow{2}{*}{$\begin{array}{l}\text { Ductility } \\
\text { ratio }\end{array}$} & \multirow{2}{*}{$\begin{array}{l}\text { Stiffness } \\
\mathrm{kN} / \mathrm{mm}\end{array}$} & \multirow{2}{*}{$\begin{array}{c}\text { Decrease in } \\
\text { ultimate } \\
\text { load (\% of } \\
\text { CSB) }\end{array}$} & \multirow{2}{*}{$\begin{array}{l}\text { Failure } \\
\text { mode }\end{array}$} \\
\hline & $\begin{array}{l}\text { Load } \\
(\mathrm{kN})\end{array}$ & $\begin{array}{c}\mathrm{D} \\
\mathrm{mm}\end{array}$ & $\begin{array}{l}\text { Load } \\
(\mathrm{kN})\end{array}$ & $\begin{array}{c}\mathrm{D} \\
\mathrm{mm}\end{array}$ & & & & & \\
\hline CSB & 63 & 4.20 & 82 & 70 & 5406 & 16.67 & 15 & - & Shear \\
\hline $\mathrm{SBWO}_{\mathrm{S}} 1$ & 43 & 4.30 & 70 & 11.50 & 543 & 2.67 & 10 & 14.63 & Shear \\
\hline $\mathrm{SBWO}_{\mathrm{S}} 2$ & 32 & 3.45 & 54 & 8.00 & 269 & 2.32 & 9.27 & 34.15 & Shear \\
\hline $\mathrm{SBWO}_{\mathrm{S}} 3$ & 16 & 2.05 & 44 & 9.00 & 247 & 4.39 & 7.80 & 46.34 & Vierendeel \\
\hline
\end{tabular}




\section{Mohamed F. Ezzat, Mohamed A. Elsabaawy and Boshra A. Eltaly "Structural Performance of Strengthened Steel Girders with Web Openings Under Shear Forces"}

The ultimate load of CSB was $82 \mathrm{kN}$ and it was the maximum ultimate load that occurred of all beams. SBWO1 has the maximum load failure of the beams with web openings which included three circular openings with $70 \mathrm{~mm}$ diameter in each shear zone. Its ultimate load was $70 \mathrm{kN}$ while it was $54 \mathrm{kN}$ for SBWOs2 which included two circular openings with $90 \mathrm{~mm}$ opening diameter in each shear zone and it was $44 \mathrm{kN}$ for SBWOs3 which included two rectangular openings at each shear zone and $90 \mathrm{~mm}$ opening depth. Steel beam with rectangular openings SBWOs3 reached yielding stage faster than other beams. SBWOs1 presented a lower ultimate load by about $14.63 \%$ than CSB. SBWOs2 presented a lower ultimate load by about $34.15 \%$ than CSB. SBWOs3 gives lower ultimate load by about $46.34 \%$ than CSB. CSB, SBWOs1 and SBWOs2 failed due to shear. SBWOs3 failed in vierendeel mechanism where the transfer of the shear force across the opening produces secondary moments in the tee beam above the opening, maximum normal stresses that happened at the rectangle openings corners (not at the lower and upper flanges of the beam), giant relation displacement between the right and the left of the opening.
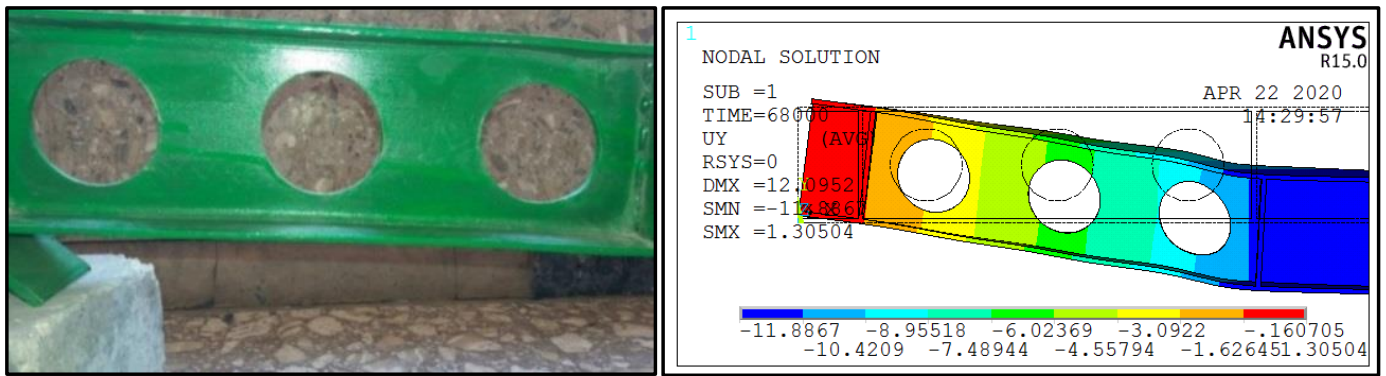

(a) SBWOs 1
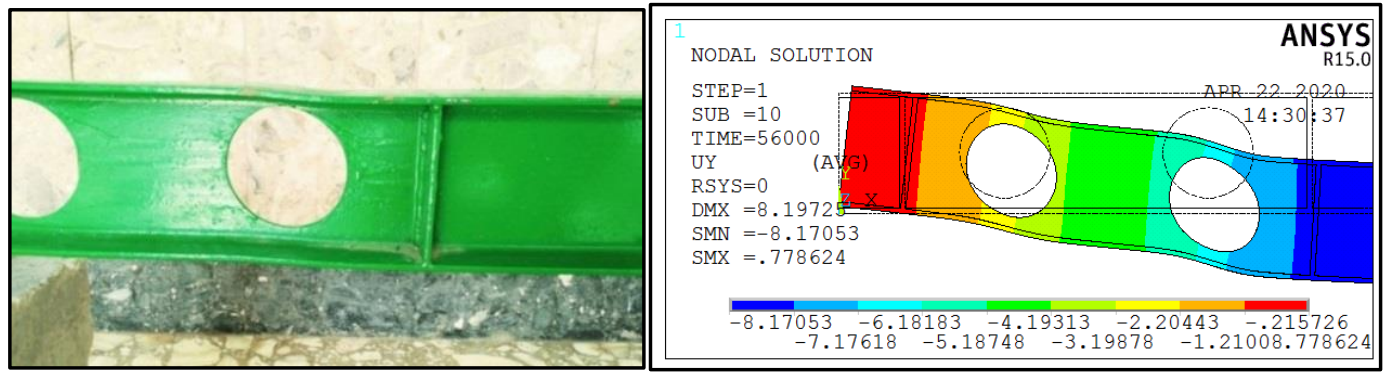

(b) SBWOs 2
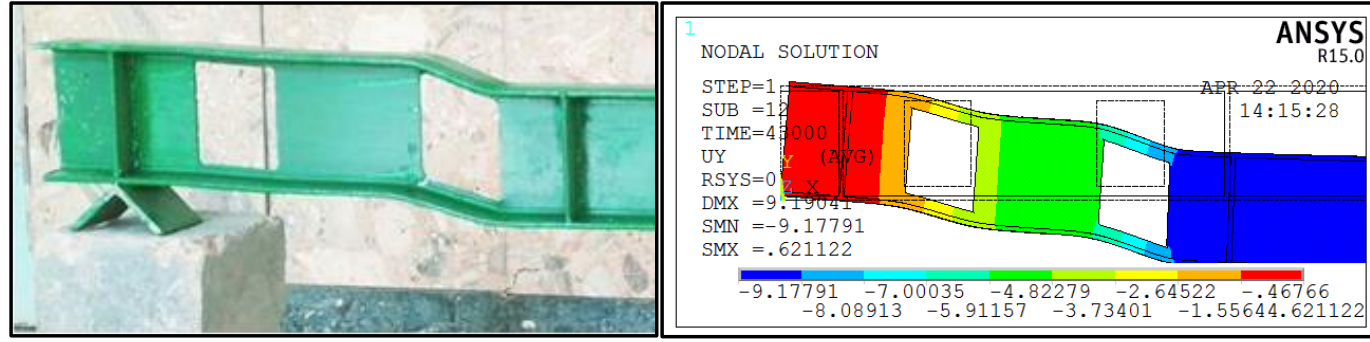

(c) SBWOs 3

Figure 4- Beam distortion of SBWOs1, SBWOs2 and SBWOs3 


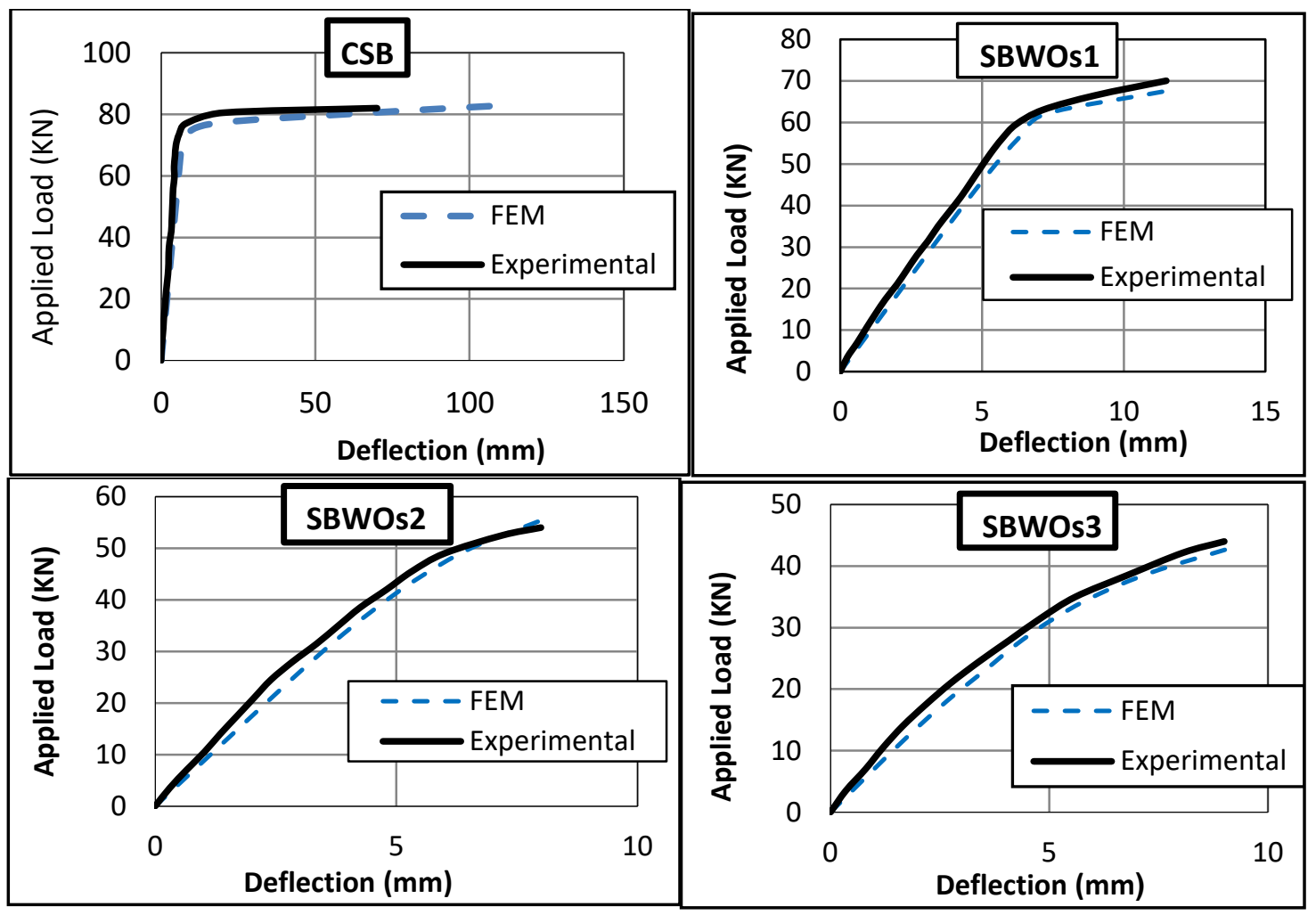

Figure 5- Load deflection curves of the four beams: experimental and FEM

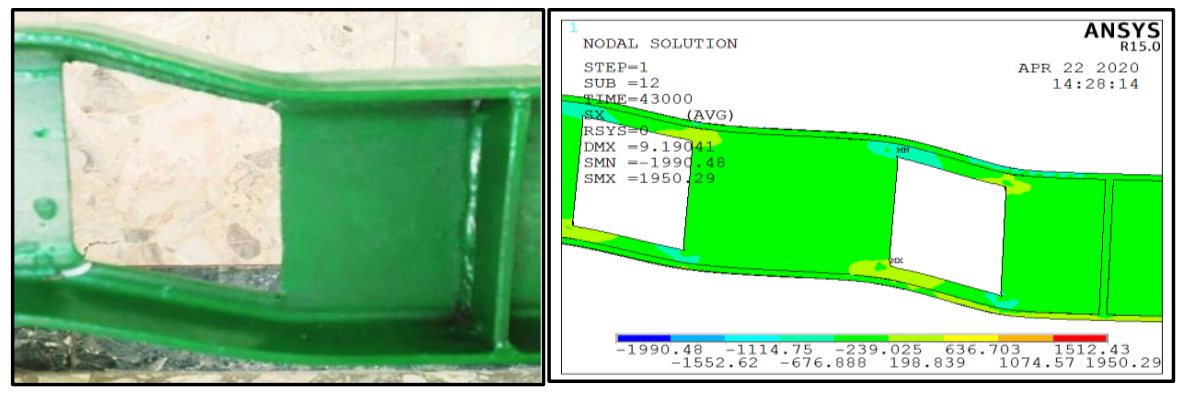

Figure 6- Normal stresses concentration

From the above where a meeting of the results between experimental and corresponding finite element, it can be found that a suitable accurateness between experimental work and FEA.

\subsection{Results of Strengthening beams}

The yielding load and the ultimate load with its corresponding mid-span deflection, the energy absorption, the stiffness, the ductility ratio and the failure mode of strengthened beams were recorded in Table (6). The results of the four beams; CSB,
SBWOs1, SBWOs2 and SBWOs3 in terms of normal and shear stress distributions and deformed shape at the maximum loads were showed in Figure (7) to Figure (10). These figures indicate that the maximum shear stress happened at the shear zones in the four beams. CSB, SBWOs1 and SBWOs2 failed due to shear stresses concentration. The ultimate shear strength of the steel material was $182 \mathrm{MPa}$. Figure (11) shows the load-deflection curves of the four beams. 
Mohamed F. Ezzat, Mohamed A. Elsabaawy and Boshra A. Eltaly "Structural Performance of Strengthened Steel Girders with Web Openings Under Shear Forces"

Table 6- Numerical results of the beams

\begin{tabular}{|c|c|c|c|c|c|c|c|c|c|}
\hline \multirow{2}{*}{$\begin{array}{l}\text { Beam } \\
\text { No. }\end{array}$} & \multicolumn{2}{|c|}{ Yield } & \multicolumn{2}{|c|}{ Ultimate } & \multirow{2}{*}{$\begin{array}{l}\text { Energy } \\
\text { Absorb. } \\
\text { kN.mm }\end{array}$} & \multirow{2}{*}{$\begin{array}{l}\text { Ductility } \\
\text { ratio }\end{array}$} & \multirow{2}{*}{$\begin{array}{c}\text { Stiffness } \\
\mathrm{kN} / \mathrm{mm}\end{array}$} & \multirow{2}{*}{$\begin{array}{c}\text { Decrease in } \\
\text { ultimate load } \\
(\% \text { of CSB })\end{array}$} & \multirow{2}{*}{$\begin{array}{l}\text { Failure } \\
\text { mode }\end{array}$} \\
\hline & $\begin{array}{c}\text { Load } \\
\mathrm{kN}\end{array}$ & $\begin{array}{c}\mathrm{D} \\
\mathrm{mm}\end{array}$ & $\begin{array}{c}\text { Load } \\
\mathrm{kN}\end{array}$ & $\begin{array}{c}\mathrm{D} \\
\mathrm{mm}\end{array}$ & & & & & \\
\hline S1SBWOs3 & 19 & 2.68 & 51 & 10.55 & 324 & 3.94 & 7.09 & 38.37 & Debonding \\
\hline S2SBWOs3 & 19 & 2.62 & 47 & 9.14 & 255 & 3.49 & 7.25 & 43.20 & Vierendeel \\
\hline S3SBWOs3 & 23 & 3.06 & 55 & 10.08 & 327 & 3.30 & 7.52 & 33.53 & Debonding \\
\hline S4SBWOs3 & 19 & 2.66 & 51 & 10.20 & 310 & 3.83 & 7.14 & 38.37 & Debonding \\
\hline S5SBWOs3 & 19 & 2.57 & 47 & 8.96 & 245 & 3.49 & 7.39 & 43.20 & Vierendeel \\
\hline S6SBWOs3 & 23 & 3.02 & 55 & 9.85 & 316 & 3.26 & 7.62 & 33.53 & Debonding \\
\hline
\end{tabular}

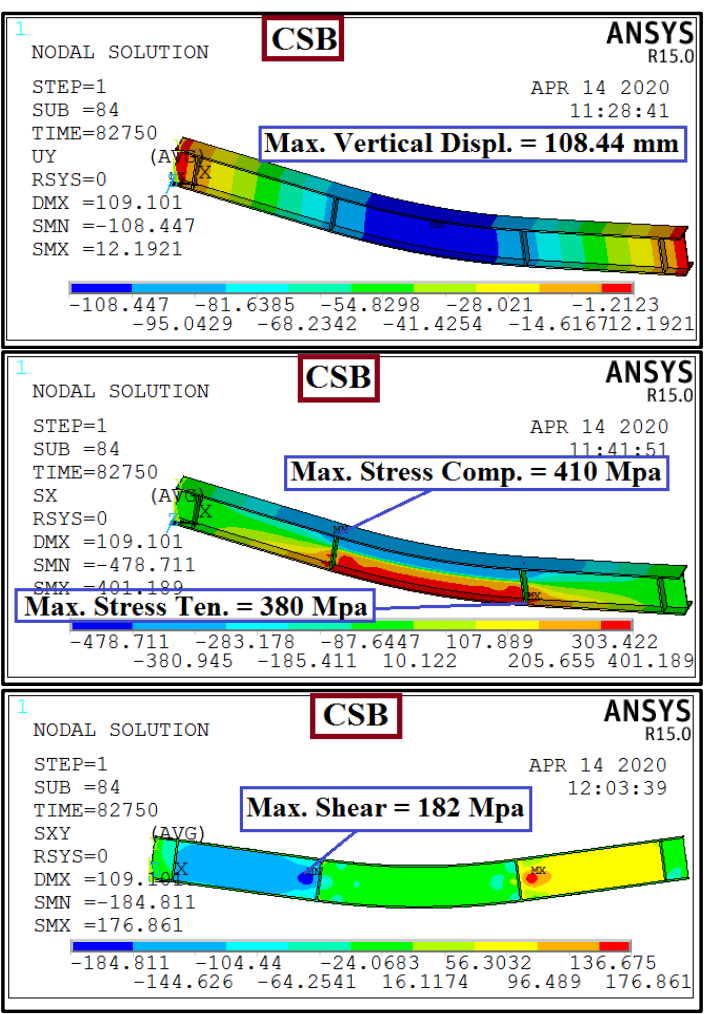

Figure 7- Results of CSB

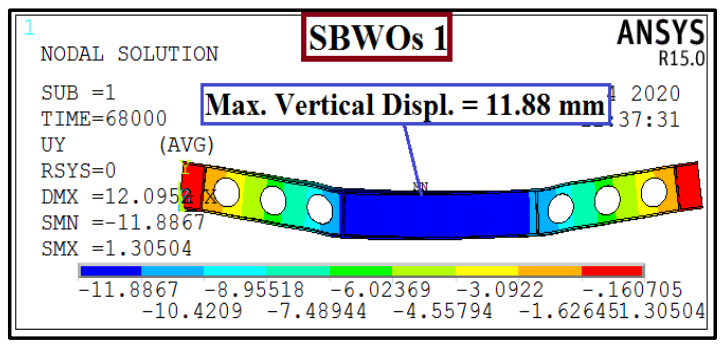

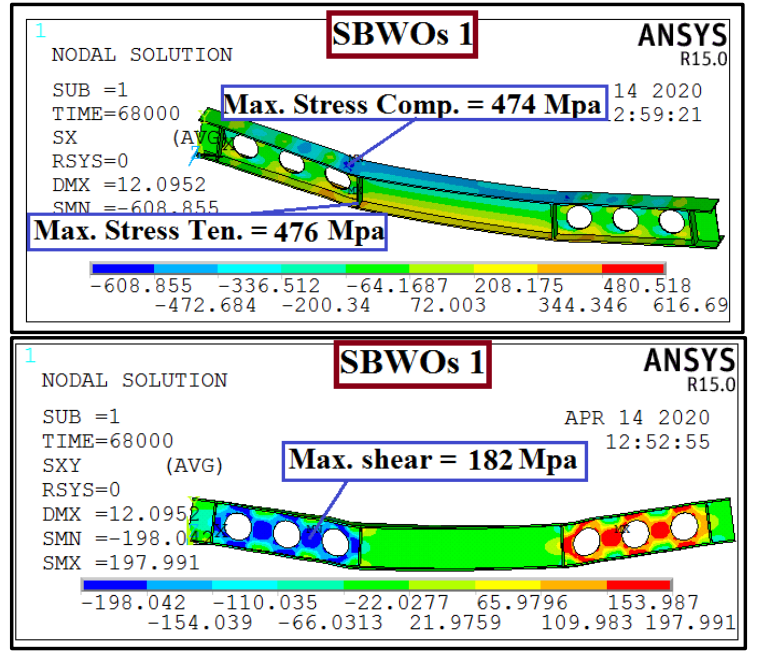

Figure 8- Results of SBWOs1

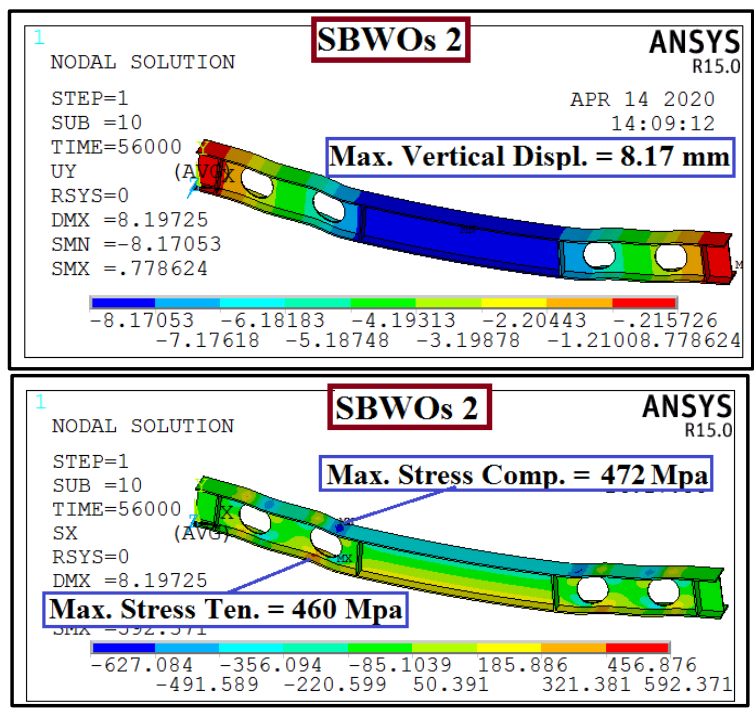




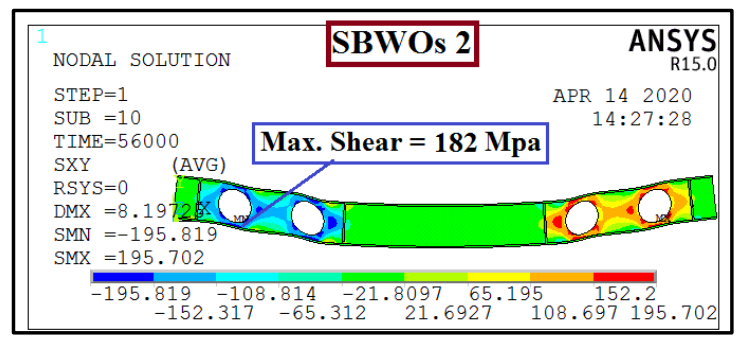

Figure 9- Results of SBWOs2

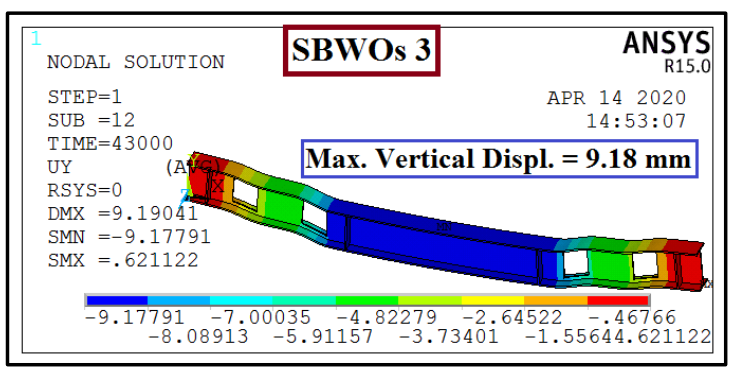

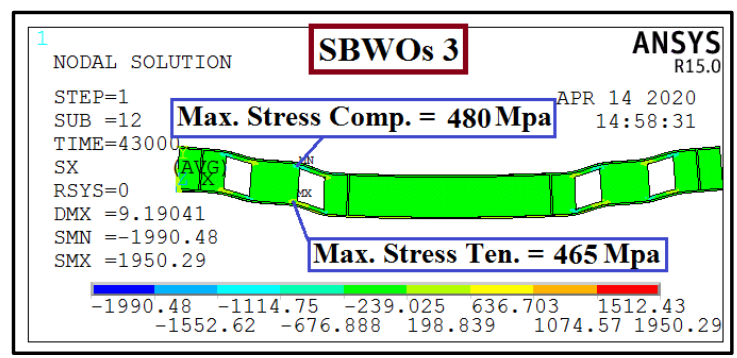

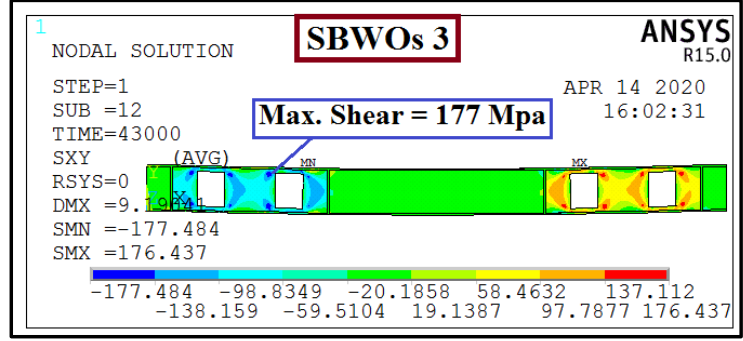

Figure 10- Results of SBWOs3

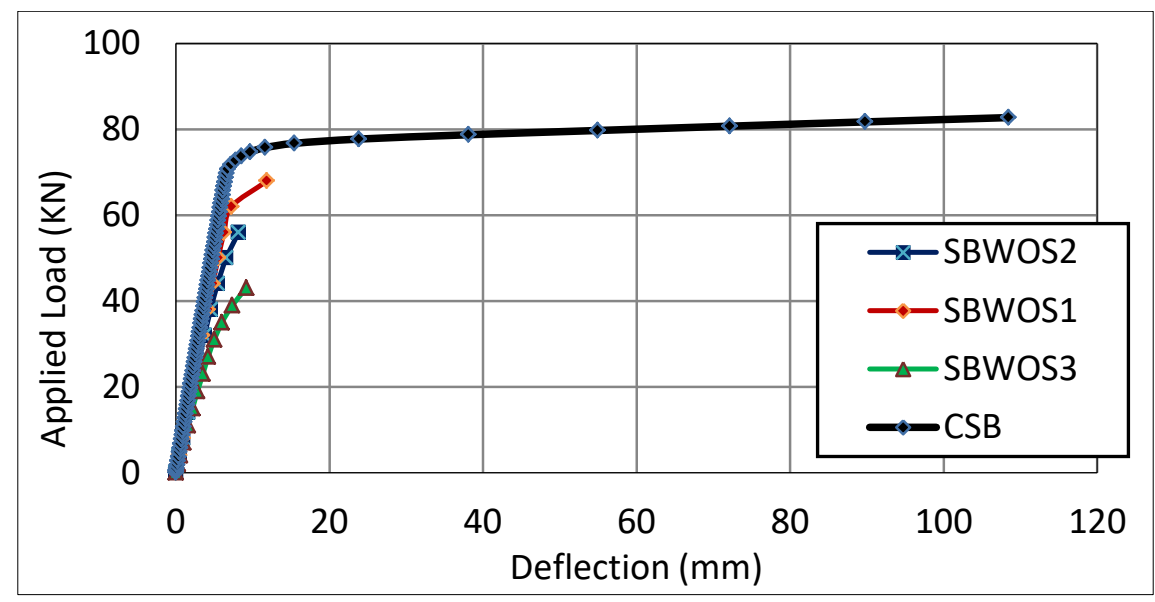

Figure 11- Load-deflection curve at the mid-span of CSB, SBWOs1, SBWOs2 and SBWOs3

Table (6) and Figure (12) to Figure (17) indicate deformed shape, normal and shear stress distributions at the maximum loads of the strengthened beams. S1SBWOs3 fails due to de-bonding where the stress of adhesive material achieves the ultimate strength 30 $\mathrm{MPa}$. Vierendel mechanism happened for S2SBWOs3 where the transfer of the shear force through the opening causes secondary moments in the tee beam overhead the opening and the maximum normal stresses happened at four corners of the rectangle openings. S3SBWOs3 fails by de-bonding where the stress of adhesive material achieves the ultimate strength $30 \mathrm{MPa}$. Table 6 and Figure (18) show the load-deflection curve of SBWOs3 and the strengthened beams which with $1.2 \mathrm{~mm}$ CFRP thickness (S1SBWOs3, S2SBWOs3 and S3SBWOs3) and indicates that ultimate load of S1BWOS2 was 51 $\mathrm{kN}$ larger than ultimate load of SBWOs3; (43 kN) with $18.6 \%$ an increase in the ultimate load, the ultimate load of S2BWOS2 was $(47 \mathrm{kN})$ more than the ultimate load of SBWOs3 $(43 \mathrm{kN})$ with $9.30 \%$ and the ultimate load of S3BWOS2 was $(55 \mathrm{kN})$ larger than the ultimate load of SBWOs3 $(43 \mathrm{kN})$ with $27.91 \%$. Note that un-strengthened beam with rectangular openings SBWOs3 failed in Vierendeel when strengthened with vertical CFRP laminates applied around the openings (S1SBWOs3) ultimate load reaches $51 \mathrm{kN}$ from $43 \mathrm{kN}$ and vierendeel mechanism not occurred but de-bonding failure between CFRP laminates and beams webs occurred. when strengthened with CFRP laminates under the lower flanges (S2SBWOs3) the beams failed in 


\section{Mohamed F. Ezzat, Mohamed A. Elsabaawy and Boshra A. Eltaly "Structural Performance of Strengthened Steel Girders with Web Openings Under Shear Forces"}

veirendeel and ultimate load reaches $47 \mathrm{kN}$ from 43 $\mathrm{kN}$ and when strengthened with vertical CFRP laminates about the openings and CFRP laminates under the lower flanges at the same time (S3SBWOs3), ultimate load reach $55 \mathrm{kN}$ and vierendeel mechanism not happened but de-bonding failure occurred. This showed that the strengthening at the openings is beneficial for increasing load capacity in case of stresses concentration about the openings. Load-deflection curves of SBWOs3 and strengthened beams with $1.4 \mathrm{~mm}$ thickness of CFRP (S4SBWOs3, S5SBWOs3, S6SBWOs3) were shown in Figure (18). Beams; S4SBWOs3, S5SBWOs3, S6SBWOs3 strengthened by CFRP laminate $1.4 \mathrm{~mm}$ thickness as like beams (S1SBWOs3, S2SBWOs3, S3SBWOs3) strengthened by CFRP laminate $1.2 \mathrm{~mm}$ thickness in failure types and failure load. The cause for that is the failure happened due to deboning (adhesive material) and not due to rupture of CFRP laminates. Figure (19) shows the load-deflection curves of S1SBWOs3 and S4SBWOs3 where ultimate load was $51 \mathrm{kN}$ with a $10.55 \mathrm{~mm}$ deflection of S1SBWOs3 and ultimate load was $51 \mathrm{kN}$ with $10.20 \mathrm{~mm}$ deflection of S4SBWOs3. Figure (19) shows the load-deflection curves of S2SBWOs3 and S5SBWOs3 where ultimate load was $47 \mathrm{kN}$ with 9.14 mm deflection of S2SBWOs3 and ultimate load was $47 \mathrm{kN}$ with $8.96 \mathrm{~mm}$ deflection of S2SBWOs3. Figure (19) shows the load-deflection curves of S3SBWOs3 and S6SBWOs3 where ultimate load 55 $\mathrm{kN}$ with $10.08 \mathrm{~mm}$ deflection of S3SBWOs3 and ultimate load was $55 \mathrm{kN}$ with $9.85 \mathrm{~mm}$ deflection of S6SBWOs3. S3SBWOs3 was the major stiffness of the strengthened beams with $1.2 \mathrm{~mm}$ CFRP laminates thickness and S6SBWOs3 was the biggest stiffness of the strengthened beams with $1.4 \mathrm{~mm}$ CFRP laminates thickness.

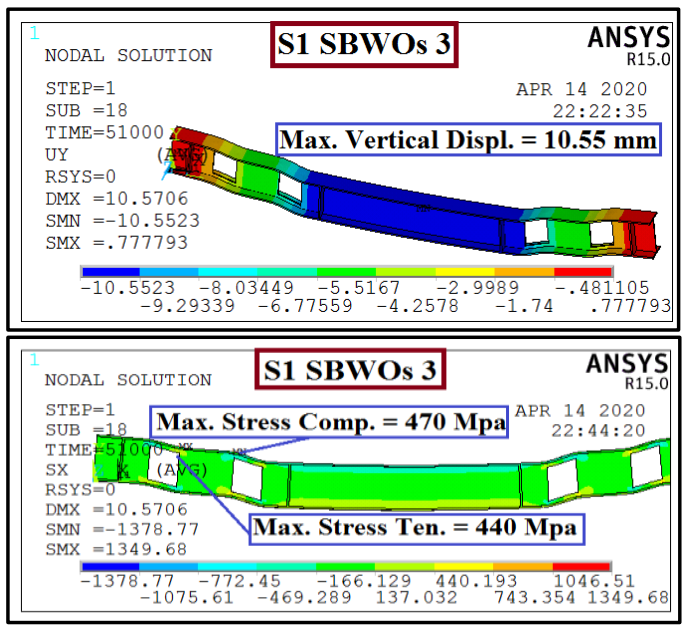

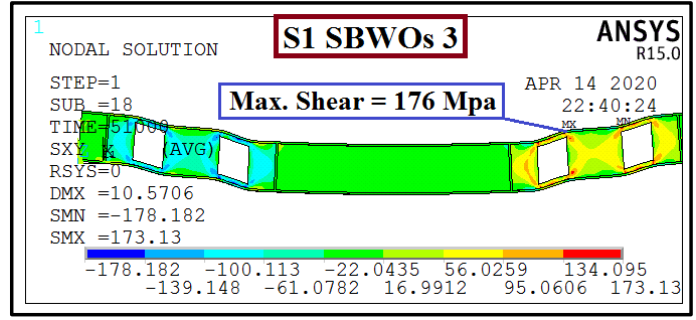

Figure 12- Results of S1SBWOs3

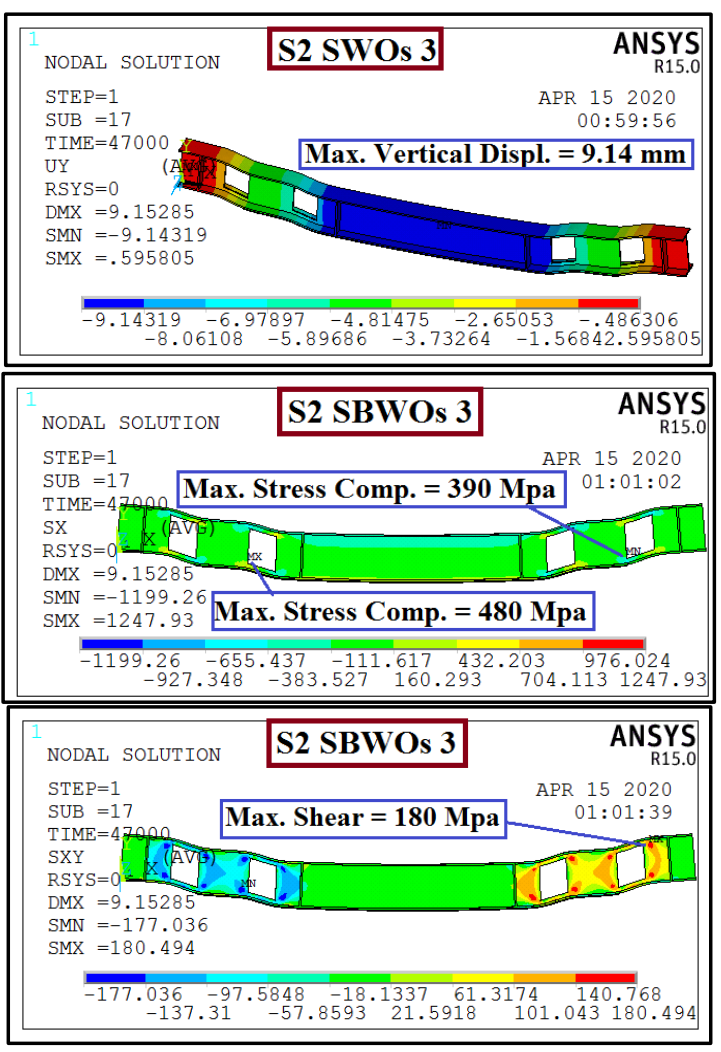

Figure 13- Results of S2SBWOs3

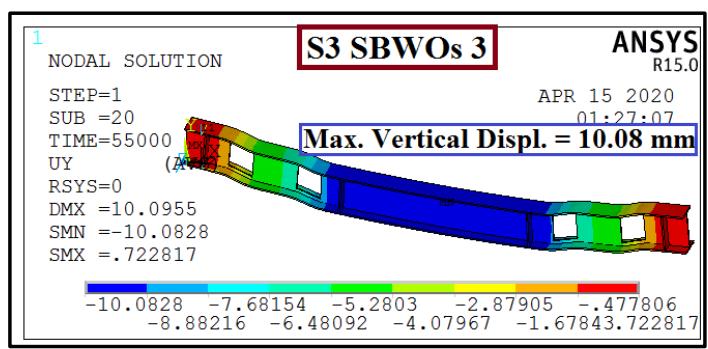



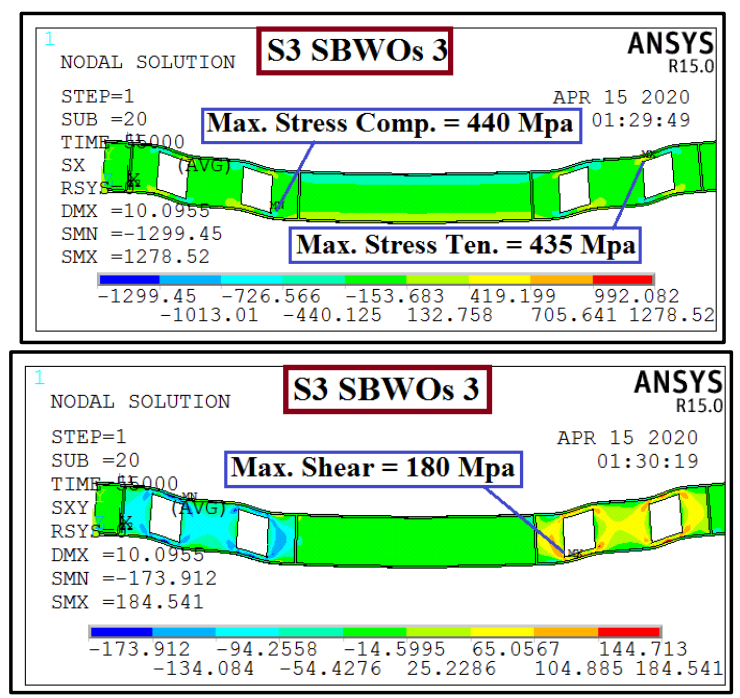

Figure 14- Results of S3SBWOs3

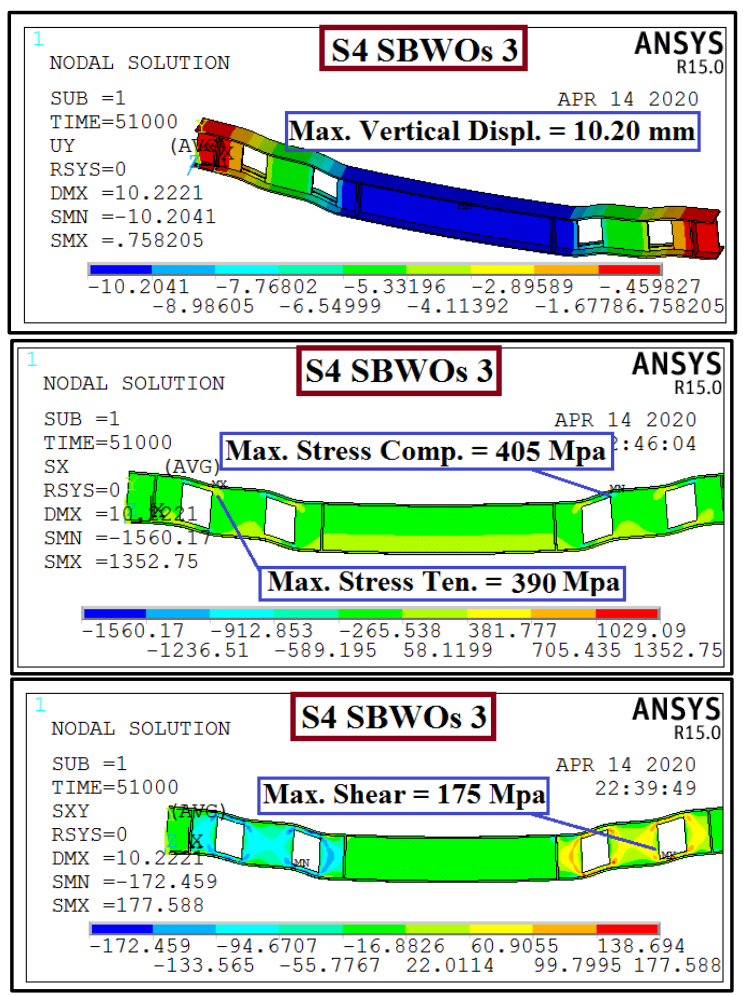

Figure 15- Results of S4SBWOs3

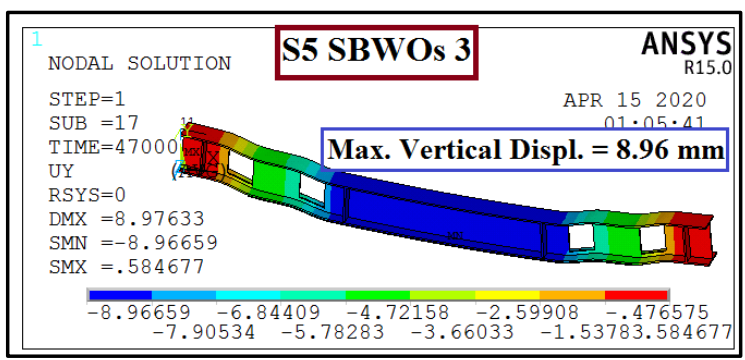

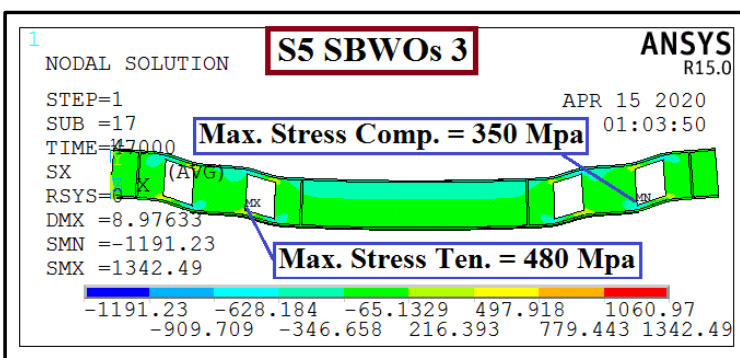

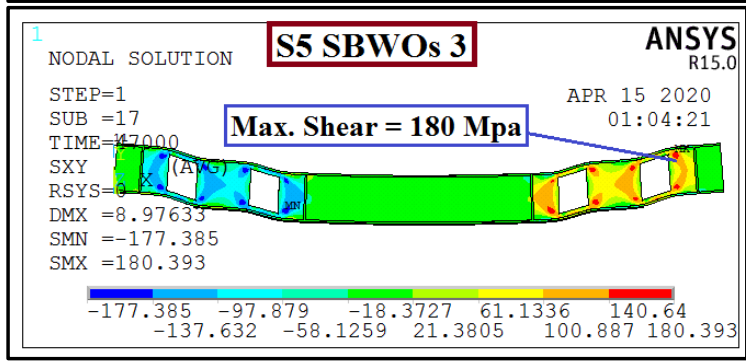

Figure 16- Results of S5SBWOs3
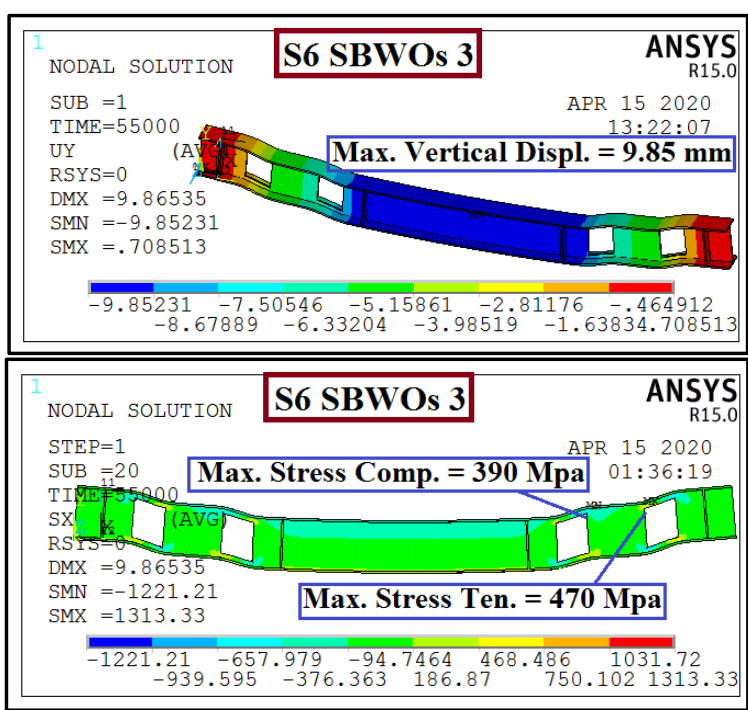
Mohamed F. Ezzat, Mohamed A. Elsabaawy and Boshra A. Eltaly "Structural Performance of Strengthened Steel Girders with Web Openings Under Shear Forces"

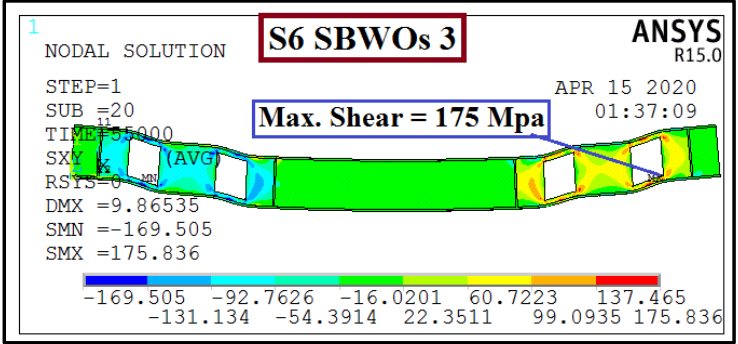

Figure 17- Results of S6SBWOs3

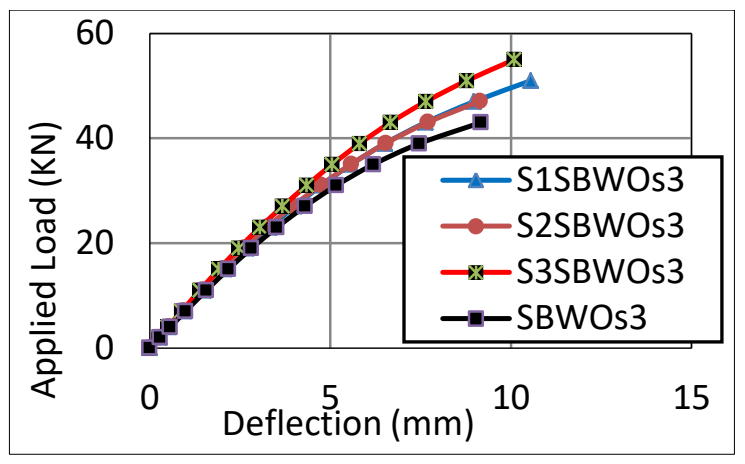

(a) SBWOs3 and beams with $1.2 \mathrm{~mm}$ CFRP.

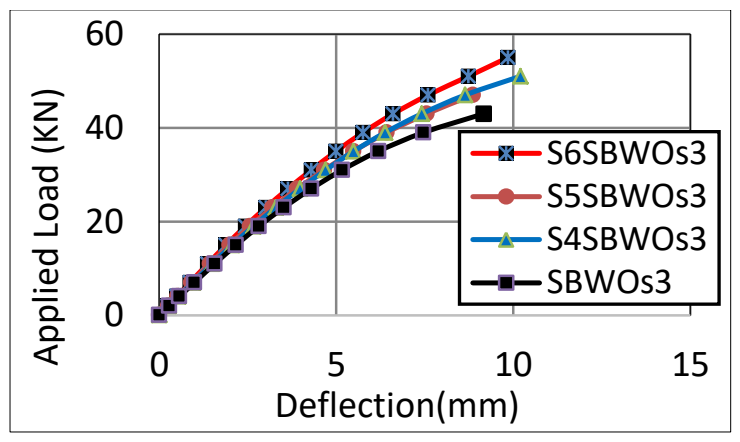

(b) SBWOs3 and beams with $1.4 \mathrm{~mm}$ CFRP.

Figure 18- Load-deflection curve at the mid-span of SBWOs3 and strengthened beams.

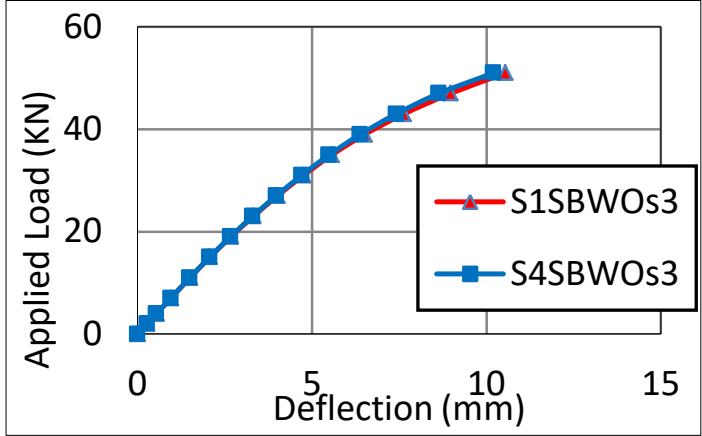

(a) S1SBWOs3 and S4SBWOs3

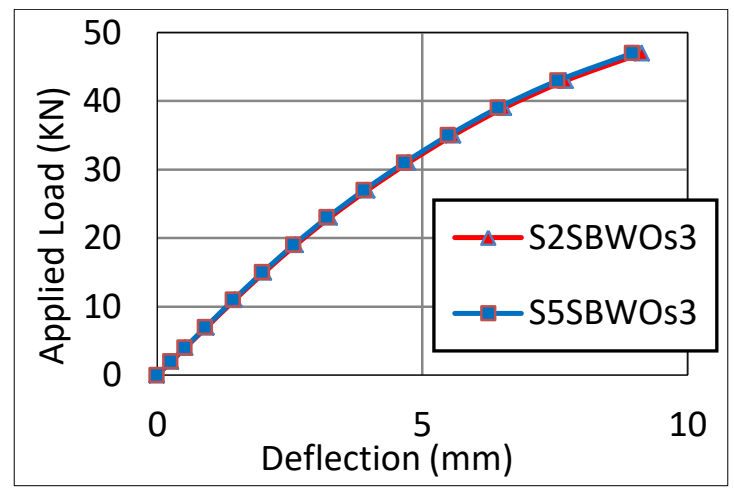

(b) S2SBWOs3 and S5SBWOs3

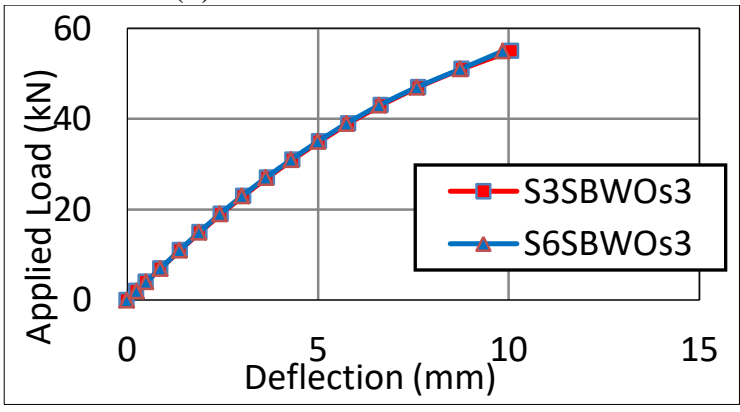

(c) S3SBWOs3 and S6SBWOs3

Figure 19- Load-deflection curve at the mid-span of strengthened beams. 


\section{Conclusions}

The structural performance of strengthened steel girders with web openings under shear forces was the goal of the present research where the variables were opening shape (circular and rectangular), opening depth and positions, thickness of CFRP laminates. Results give the bellow conclusions:

1-The circular openings gave a better performance than the rectangular openings where the ultimate load of beams with circular openings was bigger than the ultimate load of the beam with rectangular openings and the distortion shape of opening, lowed stress concentration in the beams with circular openings. Also, the ultimate load raised by reducing openings height.

2-Using CFRP for tension and shear zones was a useful strengthening choice, in the current case of study.

3-The strain reduces with a big ratio when strengthening at the openings.

4-De-bonding frequently governs the failure of strengthening before CFRP rapture.

5-Increased the thickness of CFRP was ineffective and useless wherein almost the happened failure caused by de-bonding (adhesive material) not by the rupture in CFRP laminates.

6-CFRP strengthening can be active for increasing and really improving both the strength and stiffness of steel beams after the insertion of web openings.

7-CFRP strengthening benefits over usual methods such as applying an external steel plate that contain lower self-weight, easier application and better corrosion resistance.

8-CFRP location can usually be more critical.

\section{Reference}

[1] Gupta, M., S., (2015) "An experimental and parametric study on steel beams with web openings." International Journal of Advanced Structural Engineering (IJASE), Vol. 7, No. 3: pp. 249-260.

[2] Jamadar, K., P. D., (2015) "Optimization of Opening Size for Castellated Beam with Sinusoidal Openings." Int. J. Optim. Civil Eng, Vol. 5, No. 3: pp. 301-313.

[3] Hashim, D., C., (2017) "Shapes and sizes of web opening effects on bending behavior of I-beam with web opening." AIP Conference Proceedings, Vol. 1892. No. 1.

[4] Prabhakaran, M., R., (2016) "Finite Element Analysis to Compare the Deflection of Steel Beam with and without Web Openings." IOSR Journal of Mechanical and Civil Engineering, PP. 7-11.
[5] Chung, L., T., (2003) "Steel beams with large web openings of various shapes and sizes: finite element investigation." Journal of constructional steel research, Vol. 59, No. 9: PP. 1159-1176.

[6] Hassanein, F., E., (2002) "Analysis of composite beams with web opening." 4th Structural Specialty Conference of the Canadian Society for Civil Engineering, Montréal, Québec, Canada, Vol. 1, No. 10.

[7] Longqi, L., W., (2015) "Behavior of continuous steel-concrete composite beams with web openings." International Journal of Steel Structures, Vol.15, No. 4: PP. 989-997.

[8] ElShaer, M., (2017) "Structural analysis of a composite continuous girder with a single rectangular web opening." HBRC journal, Vol. 13, No. 2: PP. 152-162.

[9] Al-Saffar, D.,B., (2015) "Flexural behavior of steel concrete composite beam with web openings and strengthened by CFRP laminates." COMPLAS XIII: proceedings of the XIII International Conference on Computational Plasticity: fundamentals and applications. CIMNE.

[10] Prakash, G., P., (2011) "Strengthening of steel beam around rectangular web openings." International Journal of Engineering Science and Technology, Vol. 3, No. 2.

[11] Motavalli, G., E., (2015) "Normal, high and ultra-high modulus carbon fiber-reinforced polymer laminates for bonded and un-bonded strengthening of steel beams." Materials \& Design, Vol. 67: pp. 232-243.

[12] Gillie, A., M., L., (2017) "Experimental investigation of CFRP-strengthened steel beams with web openings." Journal of Constructional Steel Research, Vol. 138: PP. 750-760.

[13] Sulong, N., K., M., (2010) "Investigation on end anchoring of CFRP strengthened steel Ibeams." International Journal of the Physical Sciences, Vol. 5, No. 9: PP. 1360-1371.

[14] Narmashiri, R., M., (2014) "Shear Strengthening of Steel Beams using vertical and diagonal CFRP Strips.".

[15] Kliger, L., D., M., (2010) "Performance of steel beams strengthened with CFRP laminate-Part 1: Laboratory tests." Composites Part B: Engineering, Vol. 41, No. 7: PP. 509-515. 